Nadwa | Jurnal Pendidikan Islam

Vol. 11, Nomor 2 Tahun 2017

\title{
Analisis Praktik Pelibatan Orang Tua Dan Masyarakat Dalam Kegiatan Kreatif Anak Usia Dini : Studi Kasus di TK Pertiwi Ds.Tambah Rejo, Kec. Tunjungan Kab. Blora
}

\author{
Uswatun Khasanah \\ UIN Walisongo Semarang \\ uswauswatun799@gmail.com
}

\begin{abstract}
This study aims to to analyze practices involvement parents and the community in the creative early childhood in kindergarten pertiwi. This research in a qualitative, that serves to find a meaning, investigate the process, obtain information, and having a deep understanding of an individual as well as groups.Technique data collection use observation, interviews and documentation. Data analyzed by using descriptive qualitative. The research results show that the creative done in kindergarten pertiwi is good. Types of creative activity were done in kindergarten to have a partnership with their surroundings school to support activity early childhood.
\end{abstract}

Keywords: greater involvemen, parents, the community, children, creative.

\begin{abstract}
Abstrak
Penelitian ini bertujuan untuk menganalisa praktik pelibatan orang tua dan masyarakat dalam kegiatan kreatif anak usia dini di TK Pertiwi. Penelitian ini menggunakan metode kualitatif, yang berfungsi untuk menemukan sebuah makna, menyelidiki proses, menggali informasi, serta memperoleh pemahaman yang mendalam dari individu maupun kelompok. Teknik pengumpulan data menggunakan observasi, wawancara dan dokumentasi. Data dianalisa dengan menggunakan deskriptif kualitatif. Hasil penelitian menunjukkan bahwa kegiatan kreatif yang dilakukan di TK Pertiwi sudah baik. Jenis Kegiatan kreatif yang dilakukan di Tk tersebut adalah dengan melakukan kerjasama dengan lingkungan sekitar sekolahan sebagai sarana bermain untuk menunajang kegiatan kreatif anak usia dini. untuk mendapatkan suasana yang bervariasi bagi anak.
\end{abstract}

Kata kunci: , pelibatan, orang tua,masyarakat, anak., kreatif

ISSN 1979-1739 (P) ; ISSN 2502-8057 (E).

(C) 2017 Nadwa | UIN Walisongo

http://journal.walisongo.ac.id/index.php/nadwa 


\section{Pendahuluan}

Peran serta orang tua dan masyarakat dalam kegiatan pembelajaran di TK sangatlah diperlukan untuk mendukung program yang ada di TK. Program-program di TK merupakan program yang diorientasikan untuk menumbuhkan kreativitas anak usia dini agar potensi yang ada dalam diri anak bisa terbangun. Tumbuhkembangnya potensi anak memerlukan sarana dan prasarana yang bisa menjadi wahana tempat berkreasi dan berimajinasi anak. Kebutuhan lingkungan belajar anak serta keikutsertaan orang tua dan masyarakat dalam kegiatan kreativitas anak adalah kunci untuk mengembangkan dunia anak. Alasan pentingnya keterlibatan orang tua dan masyarakat akan bisa memepercepat perkembangan dan ketuntasan TK dalam mejalankan program yang telah direncanakan. Program yang telah direncabakan akan bisa dicapai jika TK bergandengan tangan dengan orang tua dan masyarakat.

Kerjasama dengan orang tua dan masyarakat perlu diusahakan untuk terciptanya lingkungan belajar yang kondusif dan menyelaraskan program yang tertuang dalam kurikulum disekolah dengan lingkungan anak dirumah. Kerjasama yang efektif dan komunikasi dengan orang tua sangat diperlukan dalam hal yang terkait dengan kepentingan dan perkembangan anak. Orangtua perlu mengetahui keadaan anak mereka dari unsur sekolah, dan manfaat bagi guru adanya komunikasi dengan orang tua siswa, diantaranya untuk memahami perilaku anak di rumah dari masukan orang tua siswa.

Untuk dapat menciptakan suasana lingkungan yang memberi kesempatan anak untuk melakukan kegiatan kreatif secara efektif terhadap anak ketika belajar, maka diperlukannya komunikasi intensif dengan orang tua dan masyarakat sebagai mitra kerja bagi sekolah. Orang tua dan guru dapat menjadi kontributor terhadap tumbuh kembang anak. Orang tua dapat lebih baik mengenal program yang dilakukan disekolah, dan guru lebih peduli dengan situasi anak dirumah. Sebagaimana mereka belajar satu sama lain mengenai tujuan, mereka dapat saling mendukung dan bekerjasama dengan anak mereka. Guru harus memperkuat hubungan dengan orang tua. Hubungan sekolah (TK) dengan orang tua dan masyarakat akan menjadikan jalinan komunikasi semakain lancar sehingga apa yang dibutuhkan TK orang tua dan 
masyarakat bisa mengetahui dan support. Keterlibatan orang tua dalam partisipasi bidang pendidikan anak secara berkesinambungan harus terus dipelihara dan dilaksanakan secra konsistense. $^{1}$

\section{Pengertian Kegiatan Kreatif Anak Usia Dini}

Kehidupan era sekarang yang serba modern ini, tuntutan kehidupan semakin variatif, baik kebutuhan yang bersifat dharuriyat, hajiyai maupun dalam kebutuhan yang bersifat tahsiniyat. Semua itu semakin bertambah seiring dengan perkembangan zaman. Kehidupan modern ini memiliki ciri khusus yaitu: berkembangnya ilmu pengetahuan sebagai wujud dari kemajuan intelektual manusia. ${ }^{2}$ Untuk mengimbangi banyaknya tuntutan kebutuhan hidup yang semakin variatif,ditambah dengan kehidpan manusia yang serba kompetitif,maka perlu adanya sebuah kreativitas untuk memenuhi semua aspek kebutuhan manusia. Kreativitas merupakan bentuk usaha untuk memudahkan kehidupan manusia dimasa yang akan datang.

Terdapat banyak pengertian tentang kreativitas, namun hampir semua para ahli sepakat bahwa kreativitas adalah aktivitas berfikir seorang yang berbeda dengan kebiasaan berfikir orang lainnya. Berfikir meluas untuk menemukan sebuah solusi alternatif dalam sebuah permasalahan yang telah dihadapi yang telah muncul tanpa diperkirakan sebelumnya. Meskipun kreativitas banyak peresepsikan sebagai bakat alamiah sejak lahir, namun nyatanya kreativitas dapat dipelajari dan diajarkan. ${ }^{3}$

Anak Usia Dini berbeda dengan orang dewasa. Kreativitas yang dimiliki oleh orang dewasa dalam artian mampu keberadaan keahlian (exspertise), keterampilan (skills), dan motifasi dalam diri. Orang dewasa yang kreatif diartikan sebagai individu yang mempunyai keterampilan teknik yang prima dan memiliki beberapa bakat yang dimiliki. Dan juga mampu berfikir kritis,

\footnotetext{
${ }^{1}$ Rita Mariyana, dkk, Pengelolaan Lingkungan Belajar, (Jakarta:

Prenada Media, 2010), Hlm. 150-152.

${ }^{2}$ Jirhanudin, Menuju Tasawuf Dinamis, (yogyakarta: Pustaka Pelajar, 2007), Hlm. 184.

${ }^{3}$ Suyadi, Teori Pembelajaran Anak Usia Dini, (Bandung: PT Remaja Posdakarya, 2014), Hlm. 171.
} 
gagasan yang memukau serta konsentrasi dan ketekunan yang tinggi.

Kreatif pada anak-anak memiliki ciri yang khas, kreativitas anak ditandai oleh timbulnya fantasi dan imajinasi. Anak yang kreatif tidak dibatasi farme-frame tertentu, artinya mereka memiliki kebebasan untuk beraktivitas. Kemampuan Anak Usia Dini ditandai dengan kemampuan membentuk imajinasi mental dan konsep sesuatu hal yang tidak pernah muncul dihadapannya. Anak Usia Dini juga memiliki fantasi, imajinasi yang mirip dengan kehidupan nyata. ${ }^{4}$

Kreativitas anak muncul dari kemampuan berfikir meluas (divergen) untuk mencari solusi alternatif atas persoalan yang melintas tanpa diduga-duganya. Kegiatan berfikir divergen inimemiliki ciri-ciri eksploratif, generatif, tidak terduga dan menimbulkan jawaban ganda. Maka stimulasi pada otak kanan sangat penting dan esensial. Proses terjadinya kreativitas juga melibatkan berfikir konvergen yaitu melibatkan kognisi dan emosi. Yang turut terlibat aktif dalam pemberian proses kreativitas Anak Usia Dini).

Namun kreativitas itu perlu adanya stimulus (rangsangan) supaya berkembang dengan maksimal. Stimulus tersebut dapat didapatkan dari Pendidikan salah satunya melalui perantara keluarga, sekolahan dan lingkungan masyarakat. Pendidikanseharusnya mempunyai tujuan yang tepat yaitu memanusiakan manusia (humanisasi). Yang akan membuat manusia kepada fitrahnya, salah satunya dengan mengembalikan manusia menjadi manusia yang cerdas, kreatif dan inovatif, guna memperoleh kualitas hidup dan nilai-nilai kemanusiaan, Maka tugas dari pendidikan adalah mendorong manusia untuk memecahkan problema kehidupan dengan kecerdasan memecahkan permasalahan.

Oleh karenanya, Pendidikan Anak Usia Dini merupakan hal yang sangat penting, karena keberhasilan hidup seseorang didapat dengan bagaimana dia memperoleh pendidikan pada usia 5 tahun pertama tersebut. Pembentukan berbagai konsep, termasuk konsep hidup, konsep kreativitas, konsep diri dan konsep hidup.

${ }^{4}$ Tadkiroatun Musfiroh, Kreatifitas Anak Usia Dini dan Implementasi Dalam Pendidikan, JPPM / Jurnal Pendidikan dan Pemberdayaan Masyarakat. Vol. 3, No.2, Hlm. 2 
Konsep kreativitas belajar ditentukan oleh bagaimana lingkungan membentuknya (termasuk lingkungan keluarga, lingkungan masyarakat dan lingkungan sekolahan). ${ }^{5}$

Ki Hajar Dewantara berpendapat bahwa setiap anak memiliki kodratnya masing-masing, seorang pendidik hanya membantu menemukan kodratnya. Jika anak sudah mempunya kodrat baik, maka tugas pendidik adalah mengubahnya menjadi yang lebih baik lagi yaitu melalui adanya pendidikan. Karena kodrat dan lingkungan merupakan konvergensi yang saling bersinambungan satu sama lain. ${ }^{6}$

Seorang Anak dikatakan kreatif jika dia mempunyai ciri-ciri sebagai berikut:

1. Bereksplorasi, bereksperimen, memanipulasi, bermainmain, mengajukan pertanyaan yang menimbulkan jawaban ganda dan dapat mendeskripsikan suatu hal.

2. Mampu berimajinasi ketika bermain peran, dan berani bercerita di depan kelas.

3. Mampu mendemostrasikan apa yang ada difikirannya melalui bercerita

4. Mampu berkonsentrasi dalam waktu yang relatif lama

5. Anak memiliki Rasa ingin tahu yang tinggi

6. Menata sesuatu sesua dengan selera yang diinginkan oleh anak

Kreativitas anak dimulai dari membandingkan dan membedakan benda yang berada disekitarnya. Cara yang paling efektif pada pengembangan kreativitas anak usia dini adalah melalui kegiatan bermain. Karena pada dasarnya konsep pembelajaran Anak Usia Dini (AUD) adalah belajar sambil bermain. Maka tak heran jika mayoritas lembaga pendidikan (PAUD) menerapkan kegiatan bermain sebagai metode pembelajaran. $^{7}$

Bermain sebagai pendekatan ataupun strategi untuk melakukan kegiatan pembelajaran. Kegiatan belajar sebaiknya

${ }^{5}$ Tadkiroatun Musfiroh, Kreatifitas Anak Usia Dini dan Implementasi Dalam Pendidikan, JPPM / Jurnal Pendidikan dan Pemberdayaan Masyarakat, Vol. 3, No.2, Hlm. 1.

${ }^{6}$ Anita Yus, Model Pendidikan Anak Usia Dini, (Jakarta: Kencara Prenada Media,2011), Hlm. 9.

${ }^{7}$ Muhammad fauziddin, Penerapan Belajar melalui Bermain Balok Unit Untuk Meningkatkan Kreativitas Anak Usia Dini, Hlm. 3. 
memberikan peluang kepada anak untuk berkomunikasi, berfikir, logika, kemampuan intra personal, bergerak, dan bereksplorasi. Metode bermain digunakan dalam dunia anak untuk menjelajahi dunianya, mengembangkan kemampuan sebagai wujud usaha untuk mengatasi dunianya dengan mengembangkan kreativitas. Dengan metode bermain, anak bebas menentukan apa yang mereka suka tanpa adanya sebuah paksaan, anak bebas memilih sesuai dengan kemampuannya.

Dalam dunia bermain anak memiliki kesempatan untuk mengekspresikan apa yang ia rasakan ataupun yang mereka pikirkan. Anak mempraktikkan keterampilannya secara langsung melalui bermain sehingga mendapat kepuasan dalam bermain, sehingga dapat mengembangkan kreativitas yang ada pada diri anak. Selain itu anak dapat mengembangkan penalaran, imajinasi, daya fantasi dan kreativitasnya.Jenis permainan yang dapat meningkatkan kreativitas anak adalah sebagai berikut: Bermain Sandiwara Boneka, Bermain Musik, Bermain dengan APE (Alat Permainan Edukatif), Seni Tari, Berkunjung ke Musium, dan Field trip.

1. Bermain Sandiwara Boneka

Metode permainan sandiwara boneka dapat digunakan untuk meningkatkan kreativitas anak. karena metode ini memiliki berbagai kelebihan, diantaranya peserta didik akan lebih tertarik mengikuti kegiatan karena tokoh cerita berupa boneka yang beraneka ragam sehingga peserta didik lebih antusias mengikuti kegiatan bercerita. Boneka merupakan sesuatu yang sangat diminati anak, mengingat bentuknya yang lucu sehingga memperkaya imajinasinya. Panggung boneka yang didesain untuk bercerita juga meningkatkan kemampuan peserta didik untuk membangun pengetahuannya tentang isi cerita secara keseluruhan meliputi alur, tokoh, dan setting cerita. Guru juga lebih semangat untuk bercerita karena bebas berekspresi melalui tokoh boneka yang dibawanya. ${ }^{8}$

2. Bermain Musik

Seni Musik merupakan salah satustimulasi kreatif Maksudnya melibatkan tari dalam kegiatan anak berarti

${ }^{8}$ Mila Faila Shofa, Peningkatan keterampilan berbicara Anak Usia Dini Melalui Permainan Sandiwara Boneka, UMS / Jurnal Pendidikan dan Pemberdayaan Masyarakat, Vol. 1, No. 2, Hlm. 211. 2014. 
sama dengan melatih kreativitas terhadap anak. Musik merupakan salah satu bentuk seni, musik dapat mongoptimalisasi kreativitas otak. Pada bagian-bagian yang kompleks.

Keterlibatan diri dalam seni dapat meningkatkan spontanitas, rasa percaya diri, dan menghasilkan karya yang berbeda dari karya yang lain. Seni tari juga dapat digunakan untuk menghilangkan rasa takut, trauma, frustasi, dan kegagalan yang hadir ketika menciptakan karya-karya yang bersifat monumental. Aktivitasaktivitas seni juga dapat meningkatkan keterampilan memikirkankan dan membayangkan serta kemampuan berintropeksi karena pada dasarnya aktivitas seni mengharuskan menciptakan karya-karyanya dan mengevaluasi kualitas kinerja lainnya. Oleh karena itu seni harus dimasukkan kedalam kurikulum dalam Pembelajaran anak usia dini sebagai sarana pembentukan kreativitas. ${ }^{9}$

Ungkapan diri kreativitas anak itu sederhana, misalnya adalah anak mampu menirukan gerakan yang senada dengan lirik lagu. Apresiasi musik di taman kanak-kanak erat kaitannya dengan nyanyian dan gerak badan.

3. Bermain dengan APE (Alat Permainan Edukatif) Alat Permainan Edukatif (APE), adalah alat yang dirancang guna untuk keperluan pendidikan terutama pada peningkatan kreativitas anak. APE sengaja dirancang dan ditentukan secara khusus sesuai denganperkembangan, usia dan minat anak. Alat Permainan Edukatif (APE) yang dibuat harus Mengandung enam aspek yaitu: sosial emosional, nilai agama dan moral, kognitif, bahasa, seni, fisik motorik. Fungsi bermain bagi anak usia dini dapat digunakan sebaga media intervensi, jika dilakukan dengan tepat. Baik menggunakan alat ataupun tanpa alat akan sangat membantu pada perkembangan afektif, sosial emosional,

${ }^{9}$ Suyadi, Teori Pembelajaran Anak Usia Dini, (Bandung: PT Remaja Posdakarya, 2014), Hlm. 171-172. 
kognitif bahasanya. ${ }^{10}$ Jadi alat tersebut cocok digunakan sebagai media pembelajaran yang digunakan untuk meningkatkan kreativitas anak.

Alat permainan Edukatif hendaknya memperhatikan prinsip:

a. Aman, nyaman, terang, dan memenuhi kriteria bagi anak.

b. Memanfaatkan sumber daya alam yang berada di sekitar lingkungan.

c. Sesuai dengan tingkatan perkembangan anak. ${ }^{11}$

4. Seni Tari

Kehadiran seni dalam dunia pendidikan mempunyai kedudukan yang sangat penting bagi pengembangan kreatif anak usia dini. Bahkan karena begitu pentingnya tari dalam dunia pendidikan, seni seharusnya menjadi dasar pendidikan. Tanpa hadirnya pendidikan seni, pendidikan akan terasa tidak utuh.

Peran pendidikan seni merupakan kemampuan dibidang estetika dalam mewujudkan kepribadian secara utuh. Peran pendidikan seni yang bersifat multidimensional, yaitu mengembangkan kemampuan dasar manusia seperti: musik, intelektual, kreativitas dan estetik. Pendidikan seni bertujuan untuk meningkatkan kreativitas individu pada seorang anak. Pendidikan seni dapat diterapkan menggunakan pendekatan terpadu, yaitu pendekatan yang memberikan pemahaman secara holistik tentang suatu konsep atau prinsip. Belajar tentang seni yaitu meahami dan mengekspresikan serta mengekspresikan berbagai konsep ke dalam karya seni.

Oleh karenanya seni tari dijadikan sebagai sarana pengembangan kreativitas anak usia dini, dengan adanya seni tari, anak dapat menciptakan gerakan-gerakan baru yang menuangkannya kedalam sebuah tarian. ${ }^{12}$

${ }^{10}$ Muhammad fauziddin, Penerapan Belajar melalui Bermain Balok Unit Untuk Meningkatkan Kreativitas Anak Usia Dini, Curricula / Jurnal Pendidikan dan Pemberdayaan Masyarakat. Vol. 1, no.3, Hlm.5, 2016.

${ }^{11}$ Anita Yus, Model Pendidikan Anak Usia Dini, Hlm. 67.

${ }^{12}$ Eny Kusmastuti, Pendidikan Seni Tari Pada Anak Usia Dini di Taman Kanak-Kanak Tadika Puri Cabang Erlangga Semarang sebagai Proses Alih Budaya, Harmonia / Jurnal Pengetahuan dan Pemikiran seni, Vol. 5, No. 1, Hlm.4. 2004. 


\section{Faktor-faktor yang mendorong anak untuk melakukan kegiatan Kreatif}

Beberapa penelitian menunjukkan bahwa seorang anak yang mendapat rangsangan (dengan melihat, melihat, mendengar, dan bergerak) akan lebih berpeluang cerdas dibanding dengan yang tidak. Dan kasih sayang (touch) merupakan salah satu bentuk rangsangan yang sangat penting. Dengan sentuhan kasih sayang, anak akan memiliki kemampuan untuk menyatukan berbagai macam pengalaman emosialnya. Dan pondasi untuk membangun rasa aman dan kepercayaan diri pada anak adalah dengan adnya sentuhan kasih sayang.

Empat hal yang dapat mendorong anak untuk melakukan kegiatan kreatif yaitu : yang pertama, Pemberian rangsangan berupa mental baik bada aspek kognitif maupun kepribadiannya ataupun kondisi psikologis anak. Yang kedua, lingkungan yang kondusif, yang ketiga, peranan guru dalam pengembangan kreativitas anak, guru yang kreatif sangat mendukung terbentuknya kreativitas anak. Dan keempat adalah peranan orang tua dalam kegiatan kreatif anak.

1. Rangsangan Mental

Suatu karya kreatif akan muncul jika mendapat rangsangan mental yang mendukung. Pada aspek kognitif anak distimulasi agar mampu memberikan berbagai stimulan yang muncul. Pada aspek kepribadian anak distimulasi untuk mengembangkan berbagai macam potensi pribadi yang kreatif. Pada aspek psikologis (psikologikal athmosphere) di stimulasi agar anak memiliki rasa aman, kasih sayang dan penerimaan. Menerima atas segala kelebihan dan kekurangan yang telah dimiliki seorang anak, akan membuaat anak percaya diri dan berani mencoba dan berbuat sesuatu secara spontan. Dalam pengembangan kreativitas sikap tersebut sangat diperlukan.

Hal ini berarti para pendidik harus menerima semua karya anak, ini berarti wujud dukungan mental seorang pendidik kepada anak. Dengan adanya dukungan mental anak akan merasa dihargai dan diterima keberadaannya. Sehingga dia akan berkarya dan mampu memperlihatkan karyanya.

2. Iklim dan kondisi lingkungan 
Kondisi lingkungan di sekitar anak sangat mempengaruhi kegiaatan kreativitas anak, lingkungan yang sempit, kumuh, pengap dan menjenuhkan akan membuat anak merasa bosan dan tidak bersemangat untuk menemukan ide-ide barunya. Kreatif dengan sendirinya akan tumbuh berkembang dengan kondisi lingkungan yang mendukung yaitu lingkungan yang menyenangkan yang membuat seseorang menjadi senang. Montessori berpendapat bahwa lingkungan yang menyenangkan sangat menunjang pembelajaran spontan anak. Lingkungan yang menyenangkan akan dapat memunculkan kreativitas seorang anak. Pendidikan tersebut merupakan kolaborasi dengan watak anak sesuai dengan tahap-tahap perkembangannya. Interaksi tersebut kemudian masuk kedalam bagian diri mereka. Kebebasan dalam beraktivitas akan mengungkapkan tentang perkembangan anak kepada sang pendidik, yang berfungsi sebagai fasilitator atau wadah bagi kreativitas anak. ${ }^{13}$

Pemaparan diatas disimpulkan bahwa guru, orang tua dan masyarakat diharapkan untuk menyediakan lingkungan yang menyenangkan sebagai sarana pembelajaran seorang anak, karena pada dasarnya lingkungan yang menyenangkan akan membuat anak merasa nyaman, sehingga anak dapat mengembangkat kreativitasnya. ${ }^{14}$

3. Peran Kepercayaan Guru

Sebuah penelitian menunjukkan bahwa perkembangan yang optimal berasal dari kemampuan berfikir yang kraeatif yang berhubungan erat dalam cara mengajar. Sebagai seorang guru, maka harus menaruh kepercayaan penuh terhadap kemampuan anak untuk berfikir dan berani dalam mengemukakan gagasan baru ketika dan ketika anak diberi kesempatan untuk pendapat sesuai dengan apa yang anak fikirkan, dalam hal inilah kemampuan kreatif anak dapat tumbuh dengan maksimal. ${ }^{15}$

${ }^{13}$ H.E Mulyasa, Manajemen PAUD, (Bandung: Remaja Rosdakarya, 2014), Hlm. 100.

${ }^{14}$ M. Agung Hidayatullah, Lingkungan Menyenangkan Dalam Pendidikan Anak Usia Dini, Nadwa / Jurnal Pendidikan islam, Vol. 8, N0. 1, Hlm. 144, 2014.

${ }^{15}$ Utami Munandar, Pengaembangan Kreativitas Anak Berbakat, (Jakarta: Rineka Cipta, 2004), Hlm. 12 
Guru sangat berpengaruh dalam pembentukan kreativitas anak, karena pada dasarnya guru yang kreatif akan membentuk anak kreatif pula. Guru yang kreatif adalah guru yang mampu menggunakan berbagai pendekatan dalam proses kegiatan belajar mengajar. Guru harus membuat kegiatan pembelajaran yang menyenangkan. Proses belajar yang menyenangkan (joyfull teaching and learning, sanagat bermanfaat bagi perkembangan anak usia dini hingga dewasa. Menurut pontesori masa usia dini adalah fase absorbmind yaitu masa menyerap pikiran karena pada fase tersebut anak mampu menyerap semua informasi yang didapatnya melalui panca indera seperti mendengarkan dan memperhatikan. Montessori mengibaratkan seorang anak itu seperti itu sebuah spons yang menyerap air, maksudnya semua informasi yang didapatnya akan diserap denagan adanya stimulus atau rangsangan yang tepat. Jika para pendidik gagal memberikan kesan yang baik terhadap aktivitas belajar anak maka anak akan membencinya sampai tua kelak. Sebaliknya jika para pendidik memberikan kesan positif maka anak akan menyukai dan mengingatnya sampai dewasa. Selain itu juga, seorang guru mampu menciptakan kegiatan pembelajaran yang Interaktif

Pembelajaran anak usia dini tidak hanya dilakukan didalam kelas, tetapi juga diluar kelas, bahkan di luar sekolahan. Dalam proses pengembangan kreativitas anak usia dini perlu adanya sebuah pendekatan pembelajaran yang tepat bagi mereka Dalam hal tersebut perlu adanya pola pikir baru, baik pola pikir guru maupun peserta didik, sehingga menghasilkan sebuah pembelajaran yang interaktif. Pembelajaran seperti ini akan mendorong anak untuk melakukan eksplorasi terhadap lingkungan dengancara menggunakan panca inderanya seperti melihat, mendengarkan dan lain sebagainya. Pendekatan ini sejalan dengan arahan program pengembangan kreativitas anak usia dini, yang harus memberi keleluasan untuk mencari tau dan menemukan sendiri berbagai macam pengetahuan. ${ }^{16}$

4. Dukungan Orang Tua

${ }^{16}$ Yeni Rachmawati. dkk,Strategi Pengembangan Kreativitas Pada anak Usia Taman Kanak-Kanak, (Jakarta: Kencana Premedia Groub: 2010), Hlm 30-31. 
Utami munandar menjelaskan beberapa sikap orang tua yang dapat menunjang tumbuhnya kreativitas, sebagai berikut:

a. Menghargai pendapat anak dan mendorongnya untuk mengungkapkan.

b. Memberi waktu kepada anak untuk berfikir dan berkhayal.

c. Membolehkan anak mengambil keputusan sendiri.

d. Mendorong anak untuk menjajaki dan mempertanyakan suatu hal.

e. Meyakinkan anak bahwa orang tua menghargai apa yang ingin dicoba dan dilakukan.

f. Mendorong keberanian anak dalam bekerja.

g. Menjalin hubungan kerjasama dengan anak. ${ }^{17}$

Demikian adalah keempat faktor yang dapat mendorong anak untuk melakukan kegiatan kreatif anak. Keempat faktor tersebut adalah: Rangsangan Mental, Iklim dan kondisi lingkungan, Peran guru, dan peranan orang tua. Keempat faktor tersebut seharusnya diperhatikan oleh para pendidik dalam mengembangkan kreativitas anak. Dengan hal tersebut diharapkan mampu mengembangkan kreativitas anak sesuai dengan tahap perkembangannya.

\section{Strategi Pengembangan Kreativitas Anak Usia Dini}

Kreativitas merupakan aspek yang sangat penting dan harus dikembangkan pada setiap anak usia dini, karena tidak ada satu anakpun yang lahir tanpa adanya kreativitas. Seperti halnya dengan intelegensi, setiap anak memiliki kreativitas, tetapi hanya saja jenis dan tingkat kreativitas yang berbeda.

Kreativitas perlu dikembangkan sejak usia dini karena mereka memiliki rasa ingin tahu dan antusias yang tinggi terhadap suatu hal. Pengembangan kreativitas anak usia dini tersebut adalah:

1. Karya Nyata

Karya nyata dapat dijadikan sebagai usaha untuk pengembangan kreativitas anak usia dini, Melalui karya nyata anak akan menggunakan imajinasinya untuk membentuk suatu

${ }^{17}$ Yeni Rachmawati. dkk, Strategi Pengembangan Kreativitas Pada anak Usia Taman Kanak-Kanak, Hlm 32-33. 
bangunan atau benda tertentu sesuai dengan imajinasinya. Sehingga akan mendorong anak untuk menemukan ide baru bagi dirinya. Setiap anak bebas mengekspresikan kreativitasnya, sehingga sehing anak akan memperoleh hasil yang berbeda dari yang lain. Misalnya saja anak membuat permainan berupa robot dari bahan kardus.

2. Pengembangan kreativitas melalui Imajinasi

Imajinasi disebut juga dengan khayalan. Imajinasi anak-anak adalah kemampuan untuk merespon atau melakukan fantasi yang mereka buat. ${ }^{18}$

Imajinasi merupakan kemampuan berfikir luas yang dimiliki anak usia dini, yang dilakukan tanpa batas dalam merespon suatu rangsangan.Dengan imajinasi anak dapat mengembangkan kemampuan berfikir dan daya ciptanya tanpa ada batasan kenyataan realitas sehari-hari. Anak bebas berfikir sesuai dengan khayalannya. Yang menjadi catatan terpenting dalam imajinasi adalah Anak menciptakan pengetahuannya sendiri ketika dia berpartisipasi dalam permainan imajinatif.

3. Belajar Dengan Konteks nyata

Belajar dalam konteks nyata merupakan hal yang sangat penting bagi anak usia dini, karena mereka masih berada dalam proses pengembangan kognitif Pra-oprasional dan oprasional konret. Penjelasan yang dijelaskan oleh guru kepada muridnya tanpa dibarengi objek yang nyata akan sangat sulit dan membuat anak menjadi tambah bingung. Oleh karena itu eksplorasi obyek secara langsung dapat membantu proses belajar anak.

4. Eksplorasi

Ide kreatif sering kali muncul dari penjelajahan individu terhadap suatu hal. Eksplorasi dapat memberikan kesempatan kepada anak untuk melakukan sesuatu hal yang mereka suka, karena bereksplorasi sifatnya memberikan kebebasan terhadap anak. Kegiatan seperti ini biasanya dilakukan dengan mengamati secara langsung seesuai dengan keadaan yang ada disekitarnya. ${ }^{19}$

${ }^{18}$ Yeni Rachmawati. dkk,Strategi Pengembangan Kreativitas Pada anak Usia Taman Kanak-Kanak, Hlm 53.

${ }^{19}$ Yeni Rachmawati. dkk,Strategi Pengembangan Kreativitas Pada anak Usia Taman Kanak-Kanak, HIm 55. 
Upaya yang dapat dilakukan untuk mensetimulasi kreativitas anak usia dini adalah dengan memperkenalkan mereka pada alam sekitarnya. Melalui alam anak dapat diperkenalkan dengan pola kreatif, yang akan melatih mereka menjadi manusia kreatif.

\section{Tinjauan Keterkaitan Pelibatan Orang tua dan Masyarakat dalam Kegiatan Kreatif Anak Usia Dini}

Anak-anak hidup dengan lingkungan sosial, termasuk dengan keluarga, lingkungan masyarakat, pamong sekolah atau petugas lembaga, dan teman-teman sepermainannya. Ki Hajar Dewantara menggolongkan komponen lingkungan yang berperan dalam pendidikan beliau menuangkan kedalam "Tri sentra Pendidikan" yang terdiri dari lingkungan keluarga, masyarakat, dan sekolah. ${ }^{20}$ Pendidikan itu bukan hanya orang tua, tetapi sekolahan dan juga masyarakat juga ikut andil didalamnya. Sistem yang dipakai adalah sistem among, dimana konsep ini menuntut pendidik untuk bersikap yaitu : ing ngarso sungtulodo, ing madyo mangun karso, tutwuri handayani. Pendidikan dilaksanakan dengan memberi contoh/ teladan bagi anak, memberi motifasi atau dorongan dan memberi semangat pada anak supaya berkembang. ${ }^{21}$

Sayangnya,Pada saat ini masih banyak kenyatakan yang terjadi dilingkungan masyarat, bahwa yang mempunyai tanggung jawab sepenuhnya dalam hal pendidikan adalah lembaga pendidikan. Bahkan fenomena yang terjadi saat ini orang tua menyerahkan dan mempercayakan sepenuhnya kegiatan pembelajaran kepada lembaga pendidikan saja, jadi tidak heran jika orang tua berani membayar mahal biaya pendidikan. Hingga banyak orang tua yang menuntut lembaga pendidikan harus sesuai dengan apa yang diinginkan, dan kecewa jika lembaga pendidikan tidak sesuai dengan apa yang diharapkannya.

${ }^{20}$ Suyadi,dkk, Konsep Dasar PAUD, (Bandung: PT Remaja Rosdakarya, 2015), Hlm 148.

${ }^{21}$ M Syahron jaelani, Teori Pendidikan Keluarga Dan Tanggung Jawab Orang Tua dalam Pendidikan Anak Usia Dini, Nadwa / Jurnal Pendidikan Islam. Vol.8, No. 2, Oktober 2014. 
Bentuk-bentuk pelibatan orang tua dan masyarakat dalam kegiatan kreatif anak usia dini, sangat beragam diantaranya :

1. Mengadakan parenting dengan orang tua murid Menurut Selo Seomarjan, Keluarga merubagan bagian pendidikan palingpokok bagia anak, dikarenakan keluarga adalah tempat pertama kalinya anak memperoleh pengajaran, yang datang secara alamiah.Sedangkan menurut Ki Hajar Dewantara keluarga adalah kumpulan dari individu yang memiliki rasa pengabdian tanpa ada pamrih, untuk seluruh kepentingan seluruh individu didalamnya.Abdullah dan Berns berpendapat bahwa keluarga adalah sekelompok individu yang tinggal bersama di dalam satu rumah dan setiap masingmasing individu merasakan adanya kontak batin, sehingga saling memperhatikan dan menasehati dan bersosial. ${ }^{22}$

Dari ketiga pendapat diatas penulis menyimpulkan bahwa Keluarga adalah unit terkecil dari masyarakat, yang berfungsi sebagai pendidikan pertama bagi anak. Di dalam keluarga anak memperoleh pendidikan secara alamiah yang berlangsung secara kontinyu. Kita tidak akan hidup tanpa adanya sebuah keluarga, karena disitu-lah kita akan merasakan ikatan batin yang kuat sehingga terbentuklah sebuah komunikasi.Didalam keluarga anak menghabiskan waktunya untuk bermain, dan mendapatkan kasih sayang secara penuh dari dalam keluarga terutama ayah dan ibunya.

Melihat begitu pentingnya keluarga dalam pendidikan, maka lembaga pendidikan perlu mengadakan kegiatan parenting, yaitu kegiatan pertemuan antara pihak sekolah dengan wali murid. Melibatkan orang tua merupakan kegiatan sukarela yang dilakukan didalam kelas, guna untuk sharing tentang perkembangan kreativitas anak, ataupunberkomunikasi dengan guru dan melakukan kegiatan yang dapat meningkatkan kreativitas anak. Kegiatan parenting merupakan aspirasi pendidikan dan partisipasi orang tua pada anaknya. Ada beberapa kategori keterlibatan orang tua dengan masyarakat, yaitu: berkomunikasi, belajar dirumah,

${ }^{22}$ Selo Soemarjan, Sosiologi suatu pengantar, (Yogyakarta: Gajah Mada Pers, 1962). Hlm. 127. 
pembuatan keputusan, pengasuhan anak, dan melakukan kegiatan dengan sukarela. ${ }^{23}$

Henderson menyimpulkan beberapa hal berikut ini:

a. Keluarga bukanlah sekolahan yang menyediakan lingkungan pendidikan bagi anak

b. Keterlibatan orang tua dalam pendidikan formal anak meningkatkan pencapaian belajar anak.

c. Keterlibatan orang tua lebih efektif jika dilakukan secara komprehesif dan menyeluruh. ${ }^{24}$

Keterlibatan orang tua ini perlu didorong karena dapat membangun harga diri guru di hadapan anak dalam menanamkan kedisiplinan dan mengurangi problem kehidupan serta meningkatkan kreatif anak. Hasil dari riset menunjukkan bahwa pencapaian kreatif anak meningkat dengan adanya keikutsertaan orang tua di dalam sekolahPelibatan orang tua murid dan masyarakat dalam kegiatan kreatif anak.

Lingkungan keluarga, sekolahan dan masyarakat yang baik adalah itu terdiri dari sekurang-kurangnya terdiri dari 2 kriteria: yang pertama; memberikan suasana yang aman, tentram serta disayangi dan adanya perlindungan terhadap anak. Yang kedua; Mengetahui semua dasar-dasar kependidikan.

2. Mengundang orang tua untuk menghadiri pagelaran seni yang diadakan di sekolahan

Lembaga pendidikan melibatkan masyarakat dan orang tua murid dengan cara mengundangnya ke sebuah acara vestival yang dapat menunjang kreativitas anak, semisal adalah vestival seni dan budaya. ${ }^{25}$ Seperti yang dilakukan oleh PAUD di Australia.

PAUD di Australia mengadakan kolaborasi orang tua dengan pihak sekolahan dengan pertunjukan vestival seni OOTB (Out

${ }^{23}$ Made Pidarta, Manajemen Pendidikan Indonesia, (Jakarta: Rineka Cipta, 2004), Hlm. 182.

${ }^{24}$ Suyadi,dkk, Konsep Dasar PAUD, (Bandung: PT Remaja Rosdakarya, 2015), Hlm 159.

${ }^{25}$ Ade Holis, Peranan Keluarga / Orang Tua Dan Sekolah Dalam Mengembangkan Kreativitas Anak Usia Dini, Jurnal Pendidikan Universitas Garut, Vol. 01, No. 01, Hlm. 31, 2007. 
Of the Box Festival).Queensland Performing Arts Centre $(Q P A C)$ has produced and presented the Out of the Box Festival of Early Childhood (OOTB), a unique public event in Australia. OOTB is designed to enrich the creative and cultural lives of children aged 3-8 years and their communities. The biennial, week long event, is core business of the QPAC which allows children's creative activities literally to take over the complex, a major public institution situated in the centre of Brisbane. ${ }^{26}$

Queensland Performing Arts Center (QPAC) telah menghasilkan dan mempresentasikan Festival Out of the Box of Early Childhood (OOTB), sebuah acara publik yang unik di Australia. OOTB dirancang untuk memperkaya kehidupan kreatif dan budaya anak usia 3-8 tahun dan komunitas mereka, acara tersebut diadakan setiap dua minggu sekali, kegiatan tersebut merupakan bentuk dari aktivitas kreatif anak-anak secara harfiah mengambil alih kompleks, yang diselenggarakan di kota Brisbane Australia. Festival ini melibatkanketerampilan kritis dan selera para peserta muda yang cerdas, menyajikan beragam, karya luar biasa yang dimiliki oleh anak-anak.Dari kegiatan tersebut telah bekerja melibatkan berbagai pihak yaitu lembaga pendidikan, orang tua murid dan masyarakat. Lembaga pendidikan tersebut telah mengajak kerjasama dengan orang tua murid dan masyararakat, dengan cara mengundang pihak tersebut untuk menghadiri vestival seni.

\section{Metode Penelitian}

TK Pertiwi yang dijadikan obyek penelitian studi kasus ini desa. Tambahrejo, Kecamatan Tunjungan, Kabupaten Blora. TK ini berdiri pada tahun 2004, merupakan TK pertama yang ada di Tunjungan sehingga sudah memiliki banyak pengalaman dalam menjalin hubungan dengan orang tua dan masyarakat.

Jenis penelitian yang dipakai adalah penelitian kualitatif dengan menggunakan metode studi kasus (field

${ }^{26}$ ColletteTayler . dkk, Learning Partnership with Parents Of Young Children: Studying The Impact Of a Major Festival Of Early Childhood in Australia, Europen Early Childhood Education Research journal, Vol. 14, HIm. 10, 2006. 
research). Studi kasus merupakan jenis penelitian kualitatif yang berfungsi untuk menemukan sebuah makna, menyelidiki proses, menggali informasi, serta memperoleh pemahaman yang mendalam dari individu maupun kelompok. Sedangkan kasus yang diteliti dalam penelitian ini adalah analisis terhadap praktik pelibatan orang tua dan masyarakat dalam kegiatan kreatif anak usia dini.

Data dikumpulkan dengan melakukan dengan interview kepada kepada kepala sekolah, guru sebagai pendidik, orang tua murid yang ikut mendampingi anakanaknya serta masyarakat. Selain itu juga observasi kegiatan pelibatan orang tua dan masyarakat di TK Pertiwi. Serta data akan dikumpulkan dengan melihat dan memeriksa dokumen yang dimiliki TK Pertiwi dalam proses pelibatan orang tua dan masyarakat dalam membantu program kegiatan TK

\section{Masyarakat Yang Berdaya}

Pelaksanaan praktik pelibatan orang tua dan masyarakat dalam kegiatan kreatif anak usia dini di TK Pertiwi sebagai bentuk Tanggung jawab pendidikan secara bersama-saman. Pada masa ini disadari bahwa tidak hanya pada orang tua anak yang bersangkutan, tetapi semua pihak juga bersangkutan, baik terlibat secara langsung maupun tidak langsung. Pihak yang terlibat langsung di antaranya: orang tua, guru, dan lingkungan masyarakat sekitarnya.

Di samping itu, masyarakat sekitar mendukung lembaga PAUD secara aktif. Dukungan ini mulai dari penyediaan sarana dan prasarana, tenaga, alat-alat bermain, dana/ fiansial, serta dukungan lainnya. Hal tersebut sesungguhnya telah dimiliki oleh masyarakat untuk membantu dalam mensukseskan TK Pertiwi.

Keterlibatan orang tua dibentuk dalam berbagai macam hal, dan dibentuk dalam suatu ruang aktivitas didalamnya ada suatu tabel tentang keterlibatan orang tua dalam kegiatan anak. Orang tua dapat berpartisipasi secara aktif dengan menyediakan sumber belajar untuk kelas dan menjadi asisten dalam membantu guru dikelas. Keterlibatan orang tua seperti ini sangat diperlukan dalam menanamkan kebiasaan dirumah. Bahkan Orang tua 
pernah diundang dalam membuat aturan pembelajaran anak dan juga melalui kegiatan parenting. ${ }^{27}$

Secara ideal, bentuk kerjasama yang dapat dibangun antara sekolah dengan pihak masyarakat yang lebih luas. Masyarakat disini tidak hanya masyarakat yang berada disekitar sekolah saja yang dapat dilibatkan dalam program sekolah. Akan tetapi semua unsur dan pihak-pihak lain yang dapat dilibatkan untuk membantu terciptanya lingkungan belajar yang kondusif. ${ }^{28}$ Dalam pelaksanaanya, Unsur hubungan lembaga pendidikan dan masyarakat yang dapat dilibatkan dalam pemenuhan kebutuhan lingkungan belajar sekolah dengan pihak lain, lembaga pendidikan lain, yang sederajat atau lebih tinggi, perusahaan yang bergerak dibidang sarana dan prasarana belajar serta fasilitas pendidikan khususnya dibidang pendidikan TK/ SPS, pemerintahan, serta perseorangan yang ikut terlibat dalam pengadaan dan pemenuhan lingkungan belajar. Hubungan tersebut dapat dilaksanakan melalui berbagai bentuk, diantaranya dalam bentuk: laporan kepada orang tua siswa, laporan kemajuan kepada masyarakat (Public report), media cetak, media elektronik, open hause, pameran sekolah, penjelasan oleh staf, informasi dari murid tentang sekolah, laporan tahunan dan lainlain. $^{29}$

Adapun bentuk kerjasama yang dilakukan TK Pertiwi dengan masyarakat dalam hal mengembangkan kreatifitas anak adalah:

1. Penyediaan lingkungan bermain yang disediakan oleh masyarakat dan sekolahan, ${ }^{30}$

Pemanfaatan lingkungan sekitar (lingkungan masyarakat sekitar sekolahan) sebagai pemanfaatan Alat Permainan Edukatif (APE). APE yang dibutuhkan PAUD dapat dibuat atau dikembangkan bersama masyarakat dengan cara

${ }^{27}$ Wawancara dengan kepala sekolah yang berinisial HO pada bulan juni, hari sabtu, jam 08.00

${ }^{28}$ Rita Mariyana, dkk, Pengelolaan Lingkungan Belajar, Hlm. 153156.

${ }^{29}$ Nurhattati Fuad, Manajemen pendidikan berbasis masyarakat, (Jakarta: Raja Grafindo Persada, 2014), Hlm. 51.

${ }^{30}$ Hasil wawancara dengan kepala sekolah TK pertiwi yang berinisial $\mathrm{H}$ pada hari sabtu, tahun 2017 , jam 08.00 
memanfaatkan lingkungan dan kekayaan alam sekitarnya, misalnya: pasir, air, biji-bijian, kayu, tanah liat, dan lain-lain. Anak-anak menjadikan bahan tersebut sebagai bangunan seperti rumah, rumah sakit, sekolahan dan lain sebagainya. Tentunya Anak dapat menuangkan imajinasinya melalui bahan tersebut. ${ }^{31}$

Aspek positif penggunaan APE tersebut adalah secara aktif membiasakan dan mendidik serta melestarikan budaya dan kekayaan lokal yang ada di masyarakat.

2. Kerjasama dengan masyarakat melalui keikutsertaannya sarana dan prasarana sekolah terutama dalam membangun gedung sekolahan. Pertama kali TK tersebut berdiri belum mempunyai sebuah bangunan (masih numpang di rumah milik tetangga sekitar). Satu tahun kemudian bangunan sekolahnya mulai didirikan, Yang dibangun secara gotong royong dengan warga sekitar. Dengan upah, ketika anaknya sekolah disitu akan mendapat potongan SPP setengahnya. Walaupun demikian, kerjasama antara sekolah dan masyarakat sudah terbangun dengan baik, namun karena posisi kurang di pedesaan dan banyaknya kendala infra struktur telah menjadikan perkembagan kelembagaan secara umum masih belum memuaskan

Dengan adanya pelibatan orang tua dan masyarakat dalam kegiatan kreatif anak usia dini dapat meningkatkan potensi kecerdasan dan kreativitas anak usia dini, karena dapat suport dari setiap lembaga sehingga potensinya (potensi SDA dan dan potensi SDM) dapat berfungsi secara maksimal.

\section{Simpulan}

Hasil penelitian menunjukkan bahwa kegiatan kreatif yang dilakukan di TK Pertiwi di TK Pertiwi Ds.Tambah Rejo, Kec. Tunjungan Kab. Blora, dengan melibatkan orang tua dan masyarakat sangat membantu program kreativitas anak-anak TK Pertiwi terutama dalam dua hal. Pertama: Pemanfaatan lingkungan sekitar sekolahan atau milik personal sebagai sarana bermain dan tempat bermain untuk menunjang kegiatan kreatif anak usia dini, sehingga bisa untuk membantu menyusun APE.

\footnotetext{
${ }^{31}$ Hasil opservasi langsung di TK pertiwi pada hari saptu, juni, 2017 pada jam 08.00
} 
Pemanfaatan lingkungan sekitar yang disediakan masyarakat karena kerjasama dengan TK satu keuntungan yang sangat membantu memuncukan jiwa kreativitas. Kedua : keterlibatan dalam pembangunan sarana dan prasarana sekolah.

\section{Kepustakaan}

Fauziddin, Muhammad. 2016, Penerapan Belajar melalui Bermain Balok Unit Untuk Meningkatkan Kreativitas Anak Usia Dini, Curricula / Jurnal Pendidikan dan Pemberdayaan Masyarakat. Vol. 1, no.3.

Holis, Ade. 2007, Peranan Keluarga / Orang Tua Dan Sekolah

Dalam Mengembangkan Kreativitas Anak Usia Dini, Jurnal Pendidikan Universitas Garut, Vol. 01, No. 01.

Jaelani, M Syahron. 2014, Teori Pendidikan Keluarga Dan Tanggung Jawab Orang Tua dalam Pendidikan Anak Usia

Dini, Nadwa / Jurnal Pendidikan Islam. Vol. 8, No. 2.

Jirhanudin. 2007. Menuju Tasawuf Dinamis, yogyakarta: Pustaka Pelajar.

Kusmastuti, Eny. 2004, Pendidikan Seni Tari Pada Anak Usia

Dini di Taman Kanak-Kanak Tadika Puri Cabang Erlangga Semarang sebagai Proses Alih Budaya, Harmonia / Jurnal Pengetahuan dan Pemikiran seni, Vol. 5, No. 1.

Munandar, Utami. 2004, Pengaembangan Kreativitas Anak Berbakat, Jakarta: Rineka Cipta.

Musfiroh, Tadkiroatun. Kreatifitas Anak Usia Dini dan Implementasi Dalam Pendidikan, JPPM / Jurnal Pendidikan dan Pemberdayaan Masyarakat. Vol. 3, No.2.

Fuad, Nurhattati. 2014, Manajemen pendidikan berbasis masyarakat, (Jakarta: Raja Grafindo Persada,

Pidarta, Made. 2004, Manajemen Pendidikan Indonesia, jakarta: Rineka Cipta.

Rachmawati, Yeni. dkk, 2010, Strategi Pengembangan

Kreativitas Pada anak Usia Taman Kanak-Kanak, Jakarta:

Kencana Premedia Groub.

Mariyana, Rita, dkk. 2010, Pengelolaan Lingkungan Belajar, Jakarta: Prenada Media.

Suyadi, 2014. Teori Pembelajaran Anak Usia Dini, Bandung: Remaja Rosdakarya. 
Suyadi, dkk. 2015, Konsep Dasar PAUD, Bandung: Remaja Rosdakarya.

Soemarjan, Selo. 1962, Sosiologi suatu pengantar, Yogyakarta: Gajah Mada Pers.

Shofa, Mila Faila. 2014, Peningkatan keterampilan berbicara Anak Usia Dini Melalui Permainan Sandiwara Boneka, UMS / Jurnal Pendidikan dan Pemberdayaan Masyarakat, Vol. 1, No. 2.

Tayler, Collette, dkk. 2006, Learning Partnership with Parents Of Young Children: Studying The Impact Of a Major Festival Of Early Childhood in Australia, Europen Early Childhood Education Research journal, Vol. 14.

Yus, Anita. 2011, Model Pendidikan Anak Usia Dini, Jakarta: Kencara Prenada Media. 